\title{
EFFICIENCY ASSESSMENT OF VERTICAL BARRIERS ON THE BASIS OF FLOW AND TRANSPORT NUMERICAL MODELING
}

\author{
Eugeniusz Koda, Tomasz KoŁanKa, Piotr OsińsKi \\ Department of Geotechnical Engineering, Warsaw University of Life Sciences - SGGW
}

\begin{abstract}
The construction of cut-off walls is a common solution applied in such disciplines as land reclamation and landfill containment. Most commonly the construction of vertical barriers is based on cut-off wall mono or diphase technology with the use of bentonite-cement mixture as a filling material. The content of the paper is focused on groundwater flow and transport numerical modeling conducted on landfill areas where vertical bentonite barriers were constructed. The modeling process was conducted with the use of FEMWATER software which employs analysis based on finite element method. There are two examples of the software application presented in the paper which concern such case studies, i.e., reclamation of Radiowo and Łubna landfill sites. These examples are provided to prove that the appropriate investigation of ground conditions as well as definition of initial and boundary conditions and correct selection of material parameters to be fed into the software, are crucial for the overall modeling process. Moreover, the comparison of results obtained from the numerical modeling and the groundwater monitoring on site is presented for one of the case studies.
\end{abstract}

\section{INTRODUCTION}

Nowadays, the vertical barriers are constructed with the use of technologies most commonly based on deep foundation and ground reinforcement techniques [1]. The application of cut-off wall appears to be a great solution as a part of the landfill site reclamation process. The fundamental idea of cellular cut-offs is an isolating by using screen with linking cross wall at certain longitudinal distances [2]. It protects the surrounding environment against the pollutants transport and significantly decreases the level of soil and groundwater contamination. The selection process of appropriate construction technique depends on geological structure of the ground, durability and chemical resistance of the material used, also the ability of heavy machinery entrance at the site and economical factor have to be considered. Migration of the pollutants depends on geological conditions, which can be favourable to the transport of water and the substances it carries (large thickness of permeable layers, high hydraulic gradients) or it can completely stop and keep the transport away from the landfill (impermeable layers, low gradients).

The assessment of the vertical barrier influence on the migration of contaminants could be conducted with the use of numerical analysis of advective transport [3], [4]. The analysis of the modeling results is useful for a design of exact location of the vertical barrier and drainage system combined. The software that is commonly used for modeling of groundwater flow and transport is FEMWATER [5], [6]. It enables 
building the model of existing hydrogeological conditions on the site (based on field investigation) for the further prediction of hydraulic conditions after introducing engineering works. The crucial part of building the model and making it reliable is the appropriate selection of data that is going to be fed into the software. The paper is going to prove that construction of bentonite cut off wall is a reliable method in landfill reclamation process, and moreover it is shown how numerical modeling could be used to predict the behavior of groundwater flow in changed hydrogeological conditions.

\section{BENTONITE VERTICAL BARRIERS ON RADIOWO AND ŁUBNA LANDFILLS}

The most common cut-off wall constructing method is a technology of diaphragm walls made of combined still elements. They are not recommended to be constructed on contaminated landfill sites as they are not resistant to the aggressive character of landfill leachate. However, during the construction works this type of barriers is a reliable solution for temporary ground sealing. Another method of constructing cutoff walls with the use of jet-grouting technique is also quite frequently applied on sites. This type of structures is so called high-pressure vertical barriers. The method of construction is based on auger equipped with a fluid jet introduced into the ground. The mixture of water, cement and air is injected under a high pressure into the ground. After hardening the material becomes practically impermeable. A disadvantage of high-pressure vertical barriers is lack of injection depth and joints control, especially when heterogeneous ground is considered. However, this type of method eliminates the problem of excavated soil management, which is a great advantage when isolating contaminated sites where impermeable layer is investigated at a significant depth [7].

The most appropriate cut-off wall construction method for contaminated site isolation is the one utilizing basic or complex mono phase diaphragm wall technique [8]. During the excavation the sealing mixture being introduced into the ground provides the pit stability and after hardening it becomes an impermeable material protecting against migration of contaminants. However, for extremely contaminated sites complex vertical barriers are recommended. The construction of cut-off wall utilizing mono phase diaphragm wall technique has a one significant disadvantage, there is a huge amount of contaminated soil excavated that has to be properly managed and utilized only on landfills [1]. Such solutions among others, allow extending time of landfill operation [9].

The examples of introducing solutions described above is the reclamation process of Radiowo and Łubna landfills which consisted of bentonite cut-off wall construction on boundaries of the landfill body, leachate collecting drainage, degassing system, restoration of ditches, and landfill body engineering and bioengineering of landfill slopes. The scheme of the landfill where remedial works were introduced is presented in Fig. 1. 


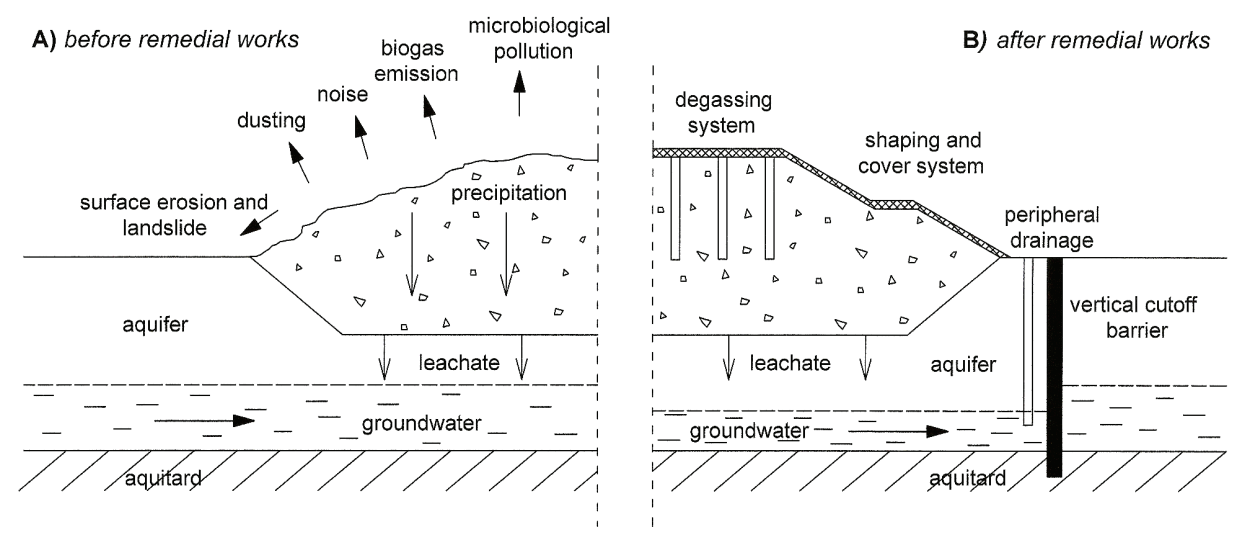

Fig. 1. Elements of remedial works applied on landfill

The vertical barriers on the two landfills mentioned were constructed in mono phase diaphragm wall technique with the use of bentonite self hardening suspension known as Solidur. The purpose of the cut-off walls was to decrease to a minimum the migration of contaminants into the aquifer of a usable groundwater level. The exact content of the suspension was determined according to the physical and chemical laboratory test results of groundwater, lecheate and soil samples. Moreover, during the full construction process the geological supervision of works had been provided, and suspension samples for laboratory tests were collected consistently. The main purpose of the laboratory tests was to determine density and permeability of the suspension, as it appears to be a crucial parameter for structures in such conditions [10], [11]. For further measurements of hydraulic conductivity there were also in situ tests conducted. They were performed with the use of BAT system as "outflow test" at the different depths of the barrier [12].

The results indicated that the coefficient of permeability of bentonite barrier makes it practically impermeable. The examples of tests presented in the paper are only small amount of all performed, however all of them proved that permeability characteristics are sufficiently promising to approve it as a reliable containment system of the landfill [11]-[13]. However, to make all the tests more reliable further research, consisting in monitoring and modeling of changed hydrogeological conditions had to be performed.

\section{FLOW AND TRANSPORT MODELING BASED ON FEMWATER}

The most reliable method of predicting the groundwater flow and transport is a numerical modeling. Such simulation could be conducted with the use of FEMWATER model (included in GMS package) [6]. To present the possibilities that the software provides, the overall idea attached to it and some examples of utilising the software in engineering reality are presented below. The basis of FEMWATER 
model is the solution of the problem of groundwater flow described by Richard's equation, using 3-D finite elements [6]. The presented model is integrated with preprocesor/postprocessor GMS (Groundwater Modelling System) [5]. The main equation for the groundwater flow modeling is a partial differential formula proposed by Richards [5]

$$
F(h) \frac{\partial h}{\partial t}=\nabla \cdot\left[k_{r} k_{s} \cdot(\Delta h+\Delta z)\right]+q
$$

where:

$F(h)$ - differential water capacity $(d \theta / d h)[\mathrm{L}-1]$,

$\theta$ - volume moisture content [L3 L-3],

$h$ - height of hydrostatic pressure [L],

$t$ - time [T],

$k_{r}$ - relative hydraulic conductivity [-],

$k_{s}-$ hydraulic conductivity tensor in saturation zone [L/T],

$z$ - location height [L],

$q-$ source element $[(\mathrm{L} 3 / \mathrm{T}) / \mathrm{L} 3]$.

In the saturation zone, $F=0$ (search to zero in FEMWATER), $\theta$ and $k_{r}$ assumed maximum values ( $\theta$ is equal to porosity, while $k_{r}=1$ ). In FEMWATER model, relations $F(h), \theta(h)$ and $k_{r}(h)$ can be defined as functions described by van Genuchten [14] or/and as linear functions. The parameter values of unsaturated zone, demanded in the numerical model, for sands were accepted on the basis of the literature data [15]-[17], while for wastes permeability parameters were determined from site tests [18].

The assumed initial conditions for the flow equation:

$$
h=h_{i}(w, y, z) \quad \text { on } R
$$

where:

$R$ - dewatering area,

$h_{i}$ - defined initial condition, which can be obtained from area investigation or from solution of flow equation (1) for established state.

Boundary conditions for flow equation:

Dirichlet's conditions:

$$
h=h_{d}\left(x_{b}, y_{b}, z_{b}, t\right) \quad \text { on } B_{d},
$$

Neumann's conditions:

$$
-n \cdot k_{r} k_{s} \cdot \nabla h=q_{n}\left(x_{b}, y_{b}, z_{b}, t\right) \quad \text { on } B_{n},
$$

Cauchy's conditions:

$$
-n \cdot k_{r} k_{s} \cdot(\nabla h+\nabla z)=q_{c}\left(x_{b}, y_{b}, z_{b}, t\right) \text { na } B_{c},
$$

where: 
$x_{b}, y_{b}, z_{b}$ - coordinates on bounds,

$n$ - unit vector is normal to bound,

$h_{d}-$ determined value of Dirichlet's functional,

$q_{n}-$ Neumann's flow,

$q_{c}-$ Cauchy's flow,

$B_{d}, B_{n}$ and $B_{c}$ - bounds, respectively by Dirichlet, Neumann and Cauchy.

There are more sophisticated "linked" conditions possible, which enable variable conditions in precipitation period or conditions in period without rainfall to be considered. The flow equation (1) subordinates both initial and boundary conditions described by equations (3)-(5). This is possible to solve by Galerkin finite elements scheme. The model can be applied both for steady flow and for the flow unstable with time. The following sets of information can be calculated and printed:

1. Information on the flow on the bound (changes velocity, increasing and the sum of flow through bounds).

2. Hydraulic height, considered as the sum of the location level and hydraulic pressure height (defined in every node).

3. The level of hydraulic pressure (defined in every node).

4. Discharge capacity (defined in every node).

5. Volume moisture content (defined at Gauss point at every element).

6. Darcy velocity (volume moisture content).

\section{FLOW MODELING - RADIOWO AND ŁUBNA CASE STUDIES}

The numerical design presented above was adopted during the prediction of hydrgeological conditions on Radiowo and Łubna landfills, and also the same approach based on Richard's equation appeared to be an appropriate method of the simulation. The purpose of design was to establish the potential directions of contaminants migration after introducing complex reclamation works. The first step of modeling was to specify the material properties to be fed into the software. The material characteristics for Radiowo and Łubna landfill are presented in Tables 1 and 2.

Table 1

Principal material properties on Radiowo landfill defined for modeling purpose

\begin{tabular}{|l|c|c|}
\hline \multicolumn{1}{|c|}{ Material/soil type } & $k_{s}[\mathrm{~m} / \mathrm{s}]$ & $\theta\left[\mathrm{cm}^{3} / \mathrm{cm}^{3}\right]$ \\
\hline Bentonite & $5 \cdot 10^{-10}$ & 0.35 \\
\hline Waste & $3 \cdot 10^{-4}$ & $0.05-0.45$ \\
\hline Fine sand with deposits & $4 \cdot 10^{-5}$ & 0.43 \\
\hline Medium and fine sand & $1 \cdot 10^{-4}$ & 0.44 \\
\hline Sandy clay & $2 \cdot 10^{-7}$ & 0.40 \\
\hline
\end{tabular}


Table 2

Principal material properties on Łubna landfill defined for modeling purpose

\begin{tabular}{|l|c|c|}
\hline \multicolumn{1}{|c|}{ Material/soil type } & $k_{s}[\mathrm{~m} / \mathrm{s}]$ & $\theta\left[\mathrm{cm}^{3} / \mathrm{cm}^{3}\right]$ \\
\hline Bentonite & $5 \cdot 10^{-10}$ & 0.35 \\
\hline Waste & $3 \cdot 10^{-4}$ & $0.05-0.45$ \\
\hline Fine sand with deposits & $4 \cdot 10^{-5}$ & 0.43 \\
\hline Medium and fine sand & $1 \cdot 10^{-4}$ & 0.44 \\
\hline Sandy clay & $2 \cdot 10^{-7}$ & 0.40 \\
\hline
\end{tabular}

The initial boundaries for the groundwater flow simulation were adopted as a steady level determined on the site before the reclamation works (construction of cut-off wall and leachate management system) were undertaken. To verify the results of modeling a comparison of values obtained from piezometric measurements was conducted (Tables 3 and 4).

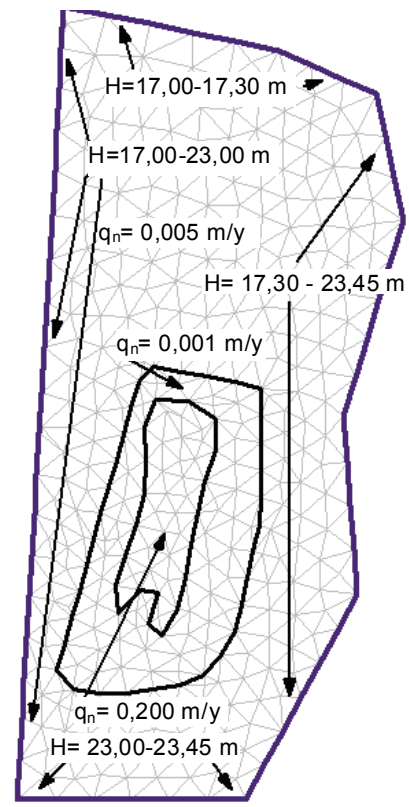

Fig. 2. Boundary conditions for transport modeling on Radiowo landfill

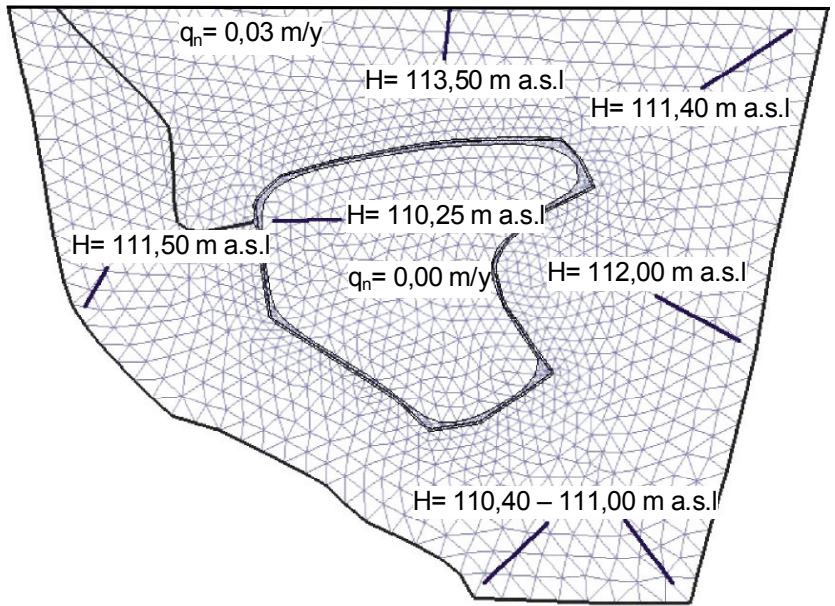

Fig. 3. Boundary conditions for transport modeling on Łubna landfill

The results of hydraulic conditions (position of water table) before and after accomplishment of reclamation works, obtained from modeling for Radiowo and Lubna landfills are presented in Figs. 4 and 5. 
Table 3

Comparison of groundwater table levels obtained from modeling and monitoring at Radiowo

\begin{tabular}{|c|c|c|c|}
\hline \multirow{2}{*}{ No. piezometer } & \multirow{2}{*}{$\begin{array}{c}\text { Terrain elevation } \\
\text { [m above "0" Vistula }]\end{array}$} & \multicolumn{2}{|c|}{ Groundwater table [m above "0" Vistula] } \\
\cline { 3 - 4 } & 23.95 & 22.86 & 22.97 \\
\hline P-4 & 23.54 & 22.65 & 22.83 \\
\hline P-6A & 23.45 & 22.19 & 22.41 \\
\hline P-7A & 23.17 & 22.39 & 22.03 \\
\hline P-9 & 20.81 & 20.57 & 20.50 \\
\hline P-10A & 20.74 & 19.93 & 20.05 \\
\hline P-11A & 20.02 & 18.46 & 18.80 \\
\hline P-15 & 17.66 & 17.04 & 17.02 \\
\hline P-17 & \multicolumn{3}{|c}{} \\
\hline
\end{tabular}

Table 4

Comparison of groundwater table levels obtained from modeling and monitoring at Łubna

\begin{tabular}{|c|c|c|c|}
\hline \multirow[b]{2}{*}{ No. piezometer } & \multirow{2}{*}{$\begin{array}{c}\text { Terrain elevation } \\
\text { [m above sea level] }\end{array}$} & \multicolumn{2}{|c|}{ Groundwater table [m above sea level] } \\
\hline & & $\begin{array}{c}\text { Measured values } \\
06.06 .2005\end{array}$ & $\begin{array}{l}\text { Values from } \\
\text { modeling }\end{array}$ \\
\hline 31 & 112,56 & 111,52 & 111,50 \\
\hline $5 a$ & 111,30 & 110,33 & 110,35 \\
\hline 4 & 111,17 & 110,67 & 110,75 \\
\hline $2 \mathrm{a}$ & 111,12 & 110,51 & 110,66 \\
\hline 16 & 111,92 & 111,10 & 111,12 \\
\hline 10 & 112,13 & 111,70 & 111,64 \\
\hline $15 \mathrm{~A}$ & 112,33 & 111,45 & 111,50 \\
\hline
\end{tabular}

a)

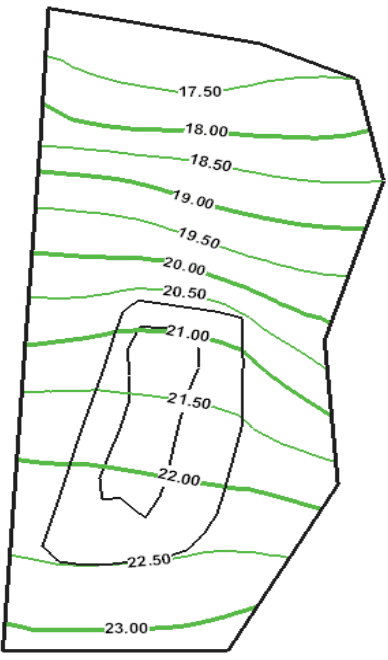

b)

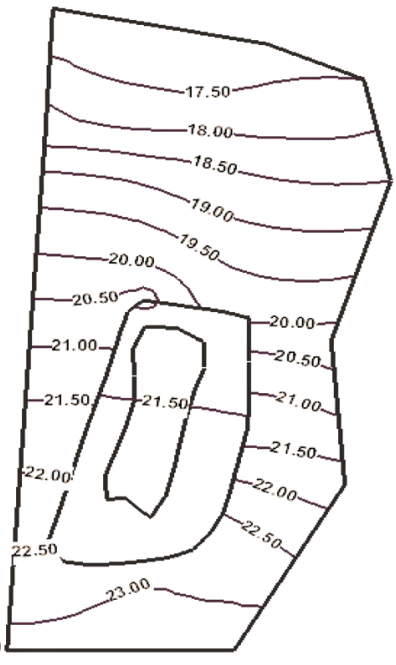

Fig. 4. Results of groundwater modeling (positions of groundwater table) for Radiowo landfill: a) before reclamation works, b) after reclamation works 
a)
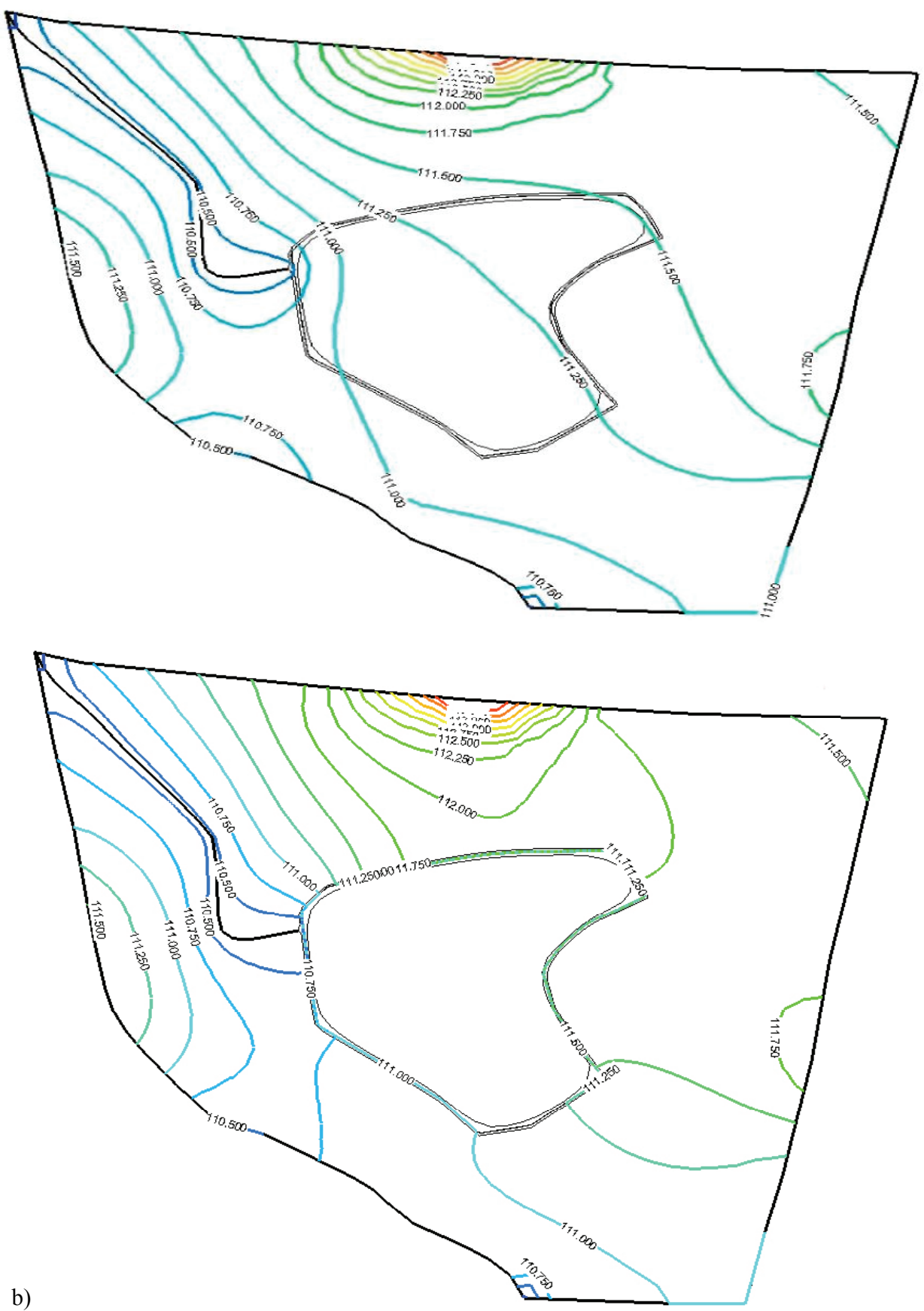

Fig. 5. Results of groundwater modeling (positions of groundwater table) for Łubna landfill: a) before reclamation works, b) after reclamation works 
All the examples given in the article refer to the prediction of groundwater flow and transport changes due to engineering works. In all case studies such works mainly consisted of cut-off wall construction [8], [9]. All of them proved that the numerical modeling could be a comprehensive method of prediction of groundwater flow, however it would be worth assessing physically whether designed models contribute with real environmental conditions. Additionally such analysis would allow assessing the effectiveness of cut-off wall construction on landfills [20].

\section{ASSESSMENT OF MODELING RELIABILITY AND EFFECTIVENESS OF VERTICAL BARRIER ON LANDFILLS}

The purpose of constructing vertical barriers on landfills is to prevent the migration of contaminants which could severely harm the nearest soil-water environment. Bearing in mind the previous experience of transport modeling performed with the use of FEMWATER, the idea of efficiency prediction for cut-off wall on Radiowo landfill was undoubtedly reasonable. The numerical modeling of pollutant migration on Radiowo landfill is presented as a map of chlorides concentration before the closure of the vertical barrier (Fig. 6a), while the situation 5 years later is presented in Fig. 6 b.
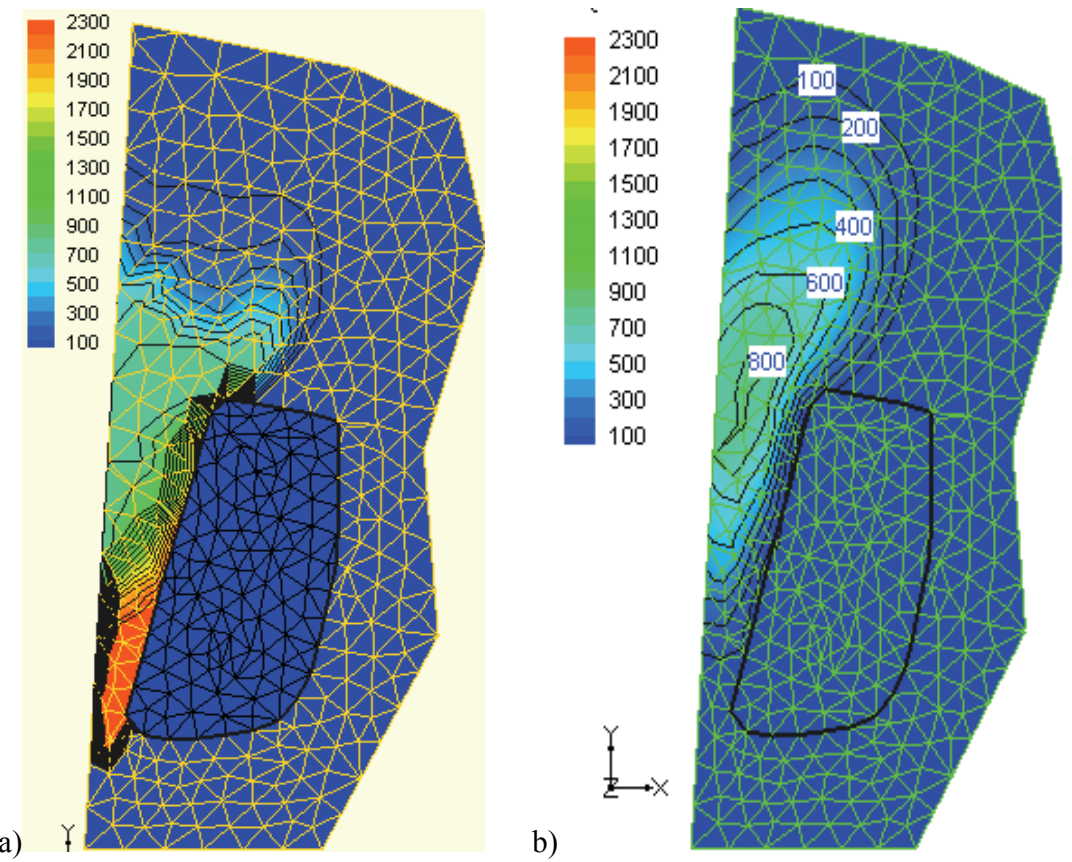

Fig. 6. Chlorides concentration $\left(\mathrm{mg} \mathrm{Cl} / \mathrm{dm}^{3}\right.$ ) at the first groundwater layer:

a) before vertical barrier construction, b) 5 years after vertical barrier construction 
To assess whether the model is reliable the information obtained from the local monitoring installed on Radiowo landfill was analysed and presented as a contour map in Figs. $7 \mathrm{a}$ and $7 \mathrm{~b}$. The values of contamination were collected from piezometers for the period covering the modeling predictions.

The results presented above show that monitored observations correspond with those obtained from modeling. The figures reveal how the concentration of contaminants decreases with time. The conclusion is that reclamation works introduced at the landfill site have significantly improved the groundwater quality. Furthermore to confirm such conclusion Table 5 is presented, where changes of values of particular pollution indicators are stated. The observations were collected from piezometer 7A identified in Fig. 7b.
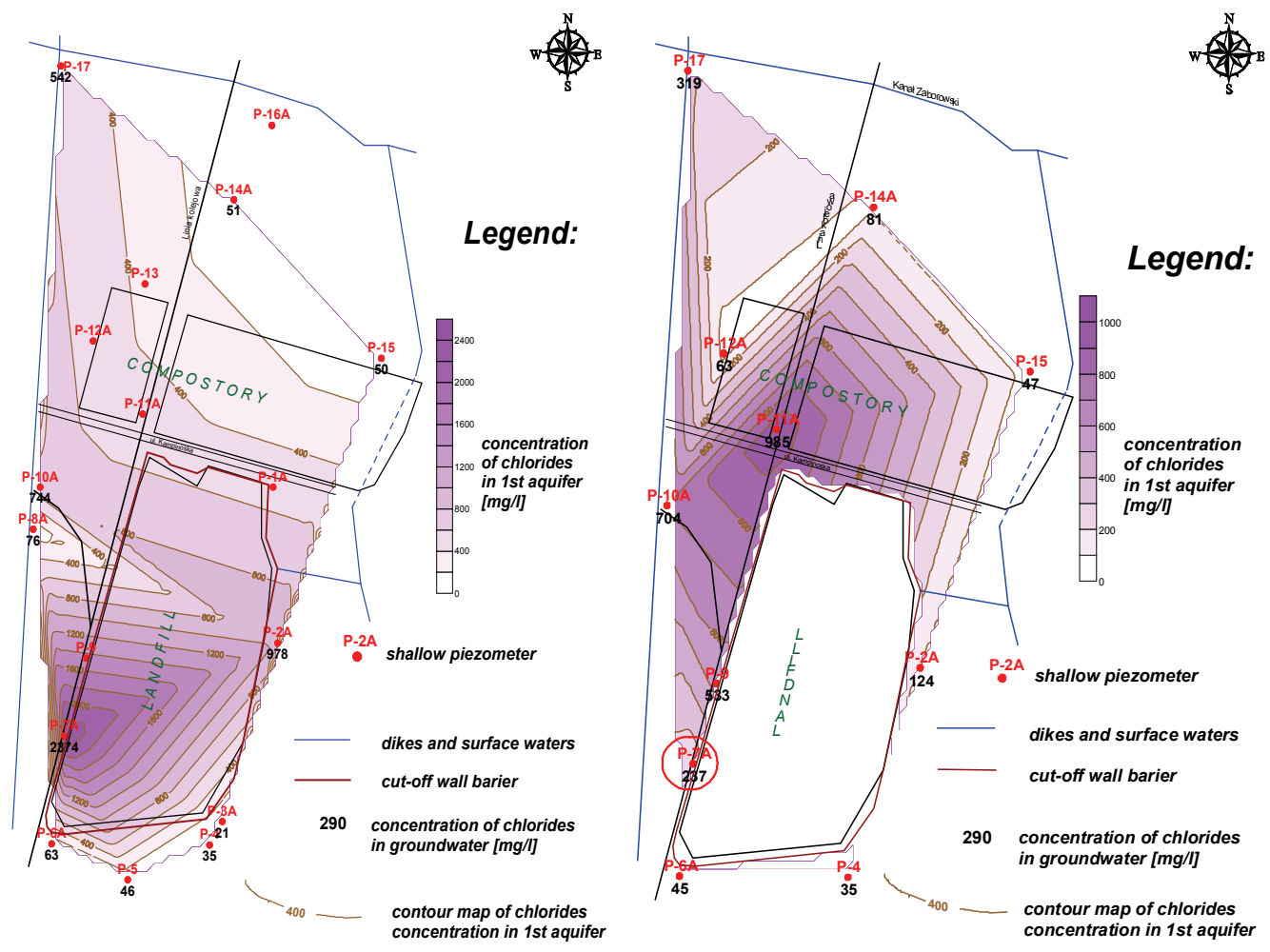

Fig. 7. Chlorides concentration $\left(\mathrm{mg} \mathrm{Cl} / \mathrm{dm}^{3}\right)$ at the first groundwater layer:

a) before the vertical barrier construction,

b) 5 years after the vertical barrier construction acc. to monitoring results 
Table 5

The influence of the vertical bentonite barrier surrounding landfill on groundwater quality at Radiowo landfill (piezometer No. 7A)

\begin{tabular}{|c|c|c|c|c|c|c|}
\hline \multirow{2}{*}{ Pollution indicator } & \multirow{2}{*}{ Unit } & \multicolumn{5}{|c|}{ Date/Concentration of pollutants } \\
\hline & & 11.07 .00 & \multirow{9}{*}{ 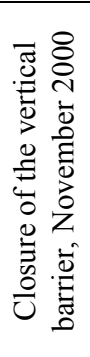 } & 20.06 .01 & 7.11 .05 & 02.03 .10 \\
\hline Electrical conductivity & $\mu \mathrm{S} / \mathrm{cm}$ & 10830 & & 8370 & 3170 & 921 \\
\hline $\mathrm{BOD}_{5}$ & $\mathrm{mgO}_{2} / \mathrm{dm}^{3}$ & 650 & & 75 & 49 & 8.5 \\
\hline $\mathrm{COD}_{\mathrm{Cr}}$ & $\mathrm{mgO}_{2} / \mathrm{dm}^{3}$ & 1758 & & 226 & 193 & 124 \\
\hline Ammonium nitrogen & $\mathrm{mgN}_{\mathrm{NH} 4} / \mathrm{dm}^{3}$ & 97.7 & & 14.1 & 0.29 & $<0,04$ \\
\hline Chlorides & $\mathrm{mgCl}^{-} / \mathrm{dm}^{3}$ & 2374 & & 1595 & 274 & 31.9 \\
\hline Sulphates & $\mathrm{mgSO}_{4}{ }^{2-} / \mathrm{dm}^{3}$ & 690 & & 630 & 805 & 131 \\
\hline Copper & $\mathrm{mgCu} / \mathrm{dm}^{3}$ & 2.1 & & 0.600 & 0.228 & 0.05 \\
\hline Lead & $\mathrm{mgPb} / \mathrm{dm}^{3}$ & 0.2 & & 0.05 & $<0.004$ & 0.005 \\
\hline
\end{tabular}

Unfortunately such simulation of contaminants migration as conducted for Radiowo, has not been conducted for Łubna landfill yet. The reason is surrounding infrastructure causing severe threats to the environment that has not been investigated properly, which could significantly influence the reliability of results. However, the assessment of vertical barrier efficiency could be performed on the basis of surface water quality readings collected from the main outflow ditch from the site at particular time. The results of the surface water quality tests are presented in Table 6.

Table 6

The influence of the vertical bentonite barrier on surface water quality at Łubna landfill

\begin{tabular}{|c|c|c|c|c|c|c|}
\hline \multirow{2}{*}{ Pollution indicator } & \multirow{2}{*}{ Unit } & \multicolumn{5}{|c|}{ Date/Concentration of pollutants } \\
\hline & & 01.06 .98 & \multirow{9}{*}{ 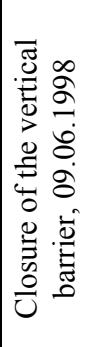 } & 16.12 .03 & 28.11 .07 & 13.09 .10 \\
\hline Electrical conductivity & $\mu \mathrm{S} / \mathrm{cm}$ & 10830 & & 8370 & 4400 & 996 \\
\hline $\mathrm{BOD}_{5}$ & $\mathrm{mgO}_{2} / \mathrm{dm}^{3}$ & 21560 & & 3450 & 1101 & 802 \\
\hline $\mathrm{COD}_{\mathrm{Cr}}$ & $\mathrm{mgO}_{2} / \mathrm{dm}^{3}$ & 10870 & & 75 & 5,2 & 2,9 \\
\hline Ammonium nitrogen & $m g N_{N H 4} / \mathrm{dm}^{3}$ & 17541 & & 238 & 80,2 & 104 \\
\hline Chlorides & $\mathrm{mgCl}^{-} / \mathrm{dm}^{3}$ & 290 & & 17,5 & 0,8 & 1,2 \\
\hline Sulphates & $\mathrm{mgSO}_{4}{ }^{2-} / \mathrm{dm}^{3}$ & 4139 & & 690 & 185 & 93,9 \\
\hline Copper & $\mathrm{mgCu} / \mathrm{dm}^{3}$ & 203 & & 130 & 100 & 69,9 \\
\hline Lead & $\mathrm{mgPb} / \mathrm{dm}^{3}$ & 0,075 & & 0,033 & 0,014 & 0,024 \\
\hline
\end{tabular}

The technical works conducted according to the reclamation project at landfill sites, including the introduced vertical bentonite barriers and drainage system to separate leachate from the landfill, helped to obtain significant improvement in the quality of groundwater (see Table 5) and surface water (see Table 6). The obtained results show that construction of the vertical barrier significantly improved the water quality in the vicinity of the landfills. In piezometer No. 7A, situated close to the place where vertical barrier was finished, a significant decrease of pollutants could be observed 
(Table 5). The most significant reduction of the pollution concentration was noted for electrical conductivity, BOD5, CODCr, ammonium nitrogen and chlorides. Presently, all pollution indicators are lower than standard values for the third quality class of groundwater. The results of the surface water quality tests performed for the Lubna landfill indicated significant reduction of $\mathrm{BOD}_{5} \mathrm{COD}_{\mathrm{Cr}}$ and ammonium nitrogen values (Table 6). Currently the quality classification of water samples fall into a range of class I and II. Only oxygen and electrical conductivity indicators are the ones which are categorized as class III. However, the improvement according to those indicators should be achieved as soon as restoration of discharging ditch No. 2 is accomplished.

\section{CONCLUSIONS}

The information on groundwater transport in modified conditions could be crucial for design processes of engineering structures [21]. The examples presented in the paper confirm that one of the highly reliable methods of modeling hydrogeological conditions could be achieved with the help of FEMWATER software. If the data to be entered to the program is properly defined the predictions could reveal very useful information corresponding to that really occurring on site. However, a designer always needs to remember that comprehensive site investigation and correct assumption of initial and boundary conditions are crucial stages during the modeling process.

As presented above the numerical modeling could also be used for the assessment of the efficiency of engineering solutions on site. For the Radiowo landfill case study the results clearly indicate that the predictions obtained from modeling correspond with those measured in piezometers. Moreover, the modelling allows assessing the cut-off wall effectiveness according to its preventing character. The examples provided proved that such solution is a reliable containment system providing the sufficient limitation to the migration of pollutants.

\section{REFERENCES}

[1] BRANDL H., Vertical barriers for municipal and hazardous waste containment, Proceedings Symposium on Developments in geotechnical Engineering, Bangkok, 1994, 301-334.

[2] Koda E., StęPIEN M., Application of Vertical Bentonite Barriers Surrounding Sanitary Landfills, 4th International Waste Forum ,Systems of Waste Management”, Poznań-Piła, 2001, 1-12.

[3] Verruijt A., Koda E., Analysis of Pollution Control by Finite Elements, Water Science and Technology Library (Vol. 12), Computational Methods in Water Resources X, Kluwer Academic Publisher, Dordrecht, 1994, Vol. 2, 1489-1495.

[4] BeAr J., Verruijt A., Modeling Groundwater Flow and Pollution, Reidel, Dordrecht, 1987.

[5] EMRL, Groundwater modeling system tutorial volume I-IV, Brigham Young University, UT, 2003. 
[6] Lin H.C., Richards D.R., Yeh G.T., Cheng J.R., Cheng H.P., Jonem N.L., FEMWATER: a threedimensional finite element computer model for simulating density-dependent flow and transport in variably saturated media, Technical Report CHL-97-12, U.S. Army Corps of Engineer, 1997.

[7] Jessberger H.L. ed., Geotechnics of Landfill Design and Remedial Works - Technical Recommendation GLR, Ernst \& Sohn, Berlin, 1993.

[8] Koda E. Groundwater Protection System for Old Landfill Leachate Containment, Proceedings of the 12th Danube-European Conference on Geotechnical Engineering, Passau, 567-570.

[9] Batog A., Hawrysz M., Geotechnical problems of raising the capacity of exploited landfill sites, Studia Geotechnica et Mechanica, 2005, Vol. XXVII, No. 1-2, 13-20.

[10] Fratalocchi E., Pasqualini E., Permeability over time of cement-bentonite slurry walls, Proceedings of the 3rd International Congress on Environmental Geotechnics, Lisboa, 1998, Vol. 2, 509-514.

[11] Lipinski M.J., Koda E., WdowsKa M.K., Assessment of key geotechnical characteristics of a groundwater protective vertical barrier, Proceedings of the 14th European Conference on Soil Mechanics and Geotechnical Engineering, Madrid, 2007, Vol. 2, 767-772.

[12] Koda E., SKUTNIK Z., Quality control tests of vertical bentonite barriers for old sanitary landfill containment, Proceedings of the 13th European Conference on Soil Mechanics and Geotechnical Engineering, Praha, 2003, Vol. 1, 409-414.

[13] Soga K., Joshi K., Long-term Performance of cement-bentonite cut-off walls: A case study, Proceedings of the $6^{\text {th }}$ International Congress on Environmental Geotechnics, New Delhi, 2010, Vol. 1, 151-164.

[14] Van GenUChten M.T., A closed-form equation for predicting the hydraulic conductivity of unsaturated soil, Soil Science Society Journal, 1980, 44, 892-898.

[15] CARSEl R.F., PARRISH R.S., Developing joint probability distribution of soilwater retention characteristics, Water Resources Research, 1988, Vol. 24, No. 5, 755-760.

[16] Rowe R.K., Quigley R.M., Broker J.R., Clayey Barrier Systems for Waste Disposal Facilities, Chapman \& Hall, London, 1995.

[17] ShaCKelford C.D., Rowe R.K., Contaminant Transport Modeling, Proceedings of the $3^{\text {rd }}$ International Congress on Environmental Geotechnics, Lisboa, 1998, Vol. 3, 939-956.

[18] Koda E., ŻAKOwicz S., Physical and hydraulics properties of the MSW for water balance of the landfill, Proceedings of the 3rd International Congress on Environmental Geotechnics, Lisboa, 1998, Vol. 1, 217-222.

[19] KodA E., Local water monitoring on surroundings of sanitary landfill, Annals of Warsaw Agricultural University - SGGW, Land Reclamation, 2004, No. 35a, 131-144.

[20] KoDA E., Assessment of efficiency of the old landfill protection system based on transport modeling and monitoring research, Proceedings of the 6th International Congress on Environmental Geotechnics, New Delhi, 2010, Vol. II, 1623-1630.

[21] KodA E., Stability and pollutant transport from remediated landfills with the use of Observational Method, SGGW, Warsaw, 2011 (in Polish). 